\title{
Sexual Dysfunction Related to Psychotropic Drugs: A Critical Review Part II: Antipsychotics
}

Authors

Affiliations

\author{
A. La Torre' ${ }^{1}$ A. Conca ${ }^{2}$, D. Duffy ${ }^{2}$, G. Giupponi², M. Pompili ${ }^{3}$, M. Grözinger ${ }^{4}$
}

${ }^{1}$ U.O. di Psichiatria, Ospedale di Rovereto, Rovereto (Tn), Italy ${ }^{2}$ Servizio Psichiatrico del Comprensorio Sanitario di Bolzano, Bolzano, Italy ${ }^{3}$ Department of Psychiatry, Sant'Andrea Hospital, “La Sapienza” University of Rome, Rome, Italy

${ }^{4}$ Klinik für Psychiatrie, Psychotherapie und Psychosomatik des Universitätsklinikums, Aachen, Germany
Key words

antipsychotic drugs

- sexual dysfunction

- sexual side effects

treatment-emergent sexual dysfunction $\begin{array}{ll}\text { received } & 21.10 .2012 \\ \text { revised } & 03.04 .2013 \\ \text { accepted } & 24.04 .2013\end{array}$

Bibliography

DOI http://dx.doi.org/

10.1055/s-0033-1347177

Published online ahead of print:

4 June 2013

Pharmacopsychiatry 2013;

46: 201-208

(c) Georg Thieme Verlag KG

Stuttgart - New York

ISSN 0176-3679

Correspondence

\section{G. Giupponi}

Psychiatrie

S Maurizio Hospital

Via Boehler 4

39100 Bolzano

Italy

Tel.: + 39/0471/909800

Fax: + 39/0471/909 819

giancarlo.giupponi@asbz.it

\section{Abstract}

$\nabla$

Sexual dysfunction is a potential side effect of antipsychotic drugs: this article presents a critical review of the current literature. Although many studies have been published on the subject, only some used a validated sexual function rating scale and most lacked either a baseline or placebo control or both. In addition, many of the studies on sexual dysfunction associated with antipsychotic medication are limited by other methodological flaws. However, there is consistent evidence to suggest that a large number of antipsychotic drugs adversely affect one or

\section{Introduction and Methods}

This study was conducted using the paper and electronic resources of the library of the Azienda Provinciale per i Servizi Sanitari (APSS) in Trento, Italy (http://atoz.ebsco.com/Titles/2793). The library has access to a wide range of databases including (DYNAMED, MEDLINE Full Text, CINAHL Plus Full Text), The Cochrane Library, Micromedex healthcare series, BMJ Clinical Evidence. The full list of available journals can be viewed at http://atoz.ebsco.com/Titles/2793, or at the APSS web site (http://www.apss.tn.it).

In completing this review, a literature search was conducted using the key words "antipsychotic drugs", "psychotropic drugs", "sexual dysfunctions", "sexual side effects", "treatment-emergent sexual dysfunction". All resulting listed articles were reviewed.

\section{Sexual Dysfunction Induced by Antipsychotics \\ $\nabla$ \\ Epidemiology}

Increasing evidence indicates that sexual dysfunction is common among patients prescribed more of the 3 phases of sexual response (desire, arousal and orgasm). Among the antipsychotics, the so called "prolactin-raising" are probably most associated with sexual dysfunction, even if further studies to confirm this are needed: the reviewed literature shows no consistent evidence that any one antipsychotic drug has a significantly superior side effect profile over another and current information on this topic is often based on methodologically weak research. Clinicians must be aware of drug-induced sexual dysfunction, since its presence can have important consequences for clinical management and compliance.

antipsychotic medication: until a few years ago, this problem was largely neglected by research teams [1-4], and sexual side effects induced by antipsychotic medication received only modest attention $[5,6]$.

The reasons for this are several. Firstly, previous research tended to focus mainly on the effects of the underlying disease on the patient's sexuality, describing sexual disorders and behaviour associated with psychotic symptoms [7-9]. Secondly, patients, especially those suffering from schizophrenia, rarely spontaneously report sexual dysfunction [10]. In addition, similar to patients taking antidepressants, patients with psychosis are more likely to report sexual side effects if directly questioned about them. Studies that relied only on spontaneous reporting of side effects, report low rates of sexual dysfunction, while studies using structured interviews or questionnaires show higher rates of sexual dysfunction $[3,11,12]$. Despite this finding, in clinical practice psychiatrists often continue to underestimate the importance of formally enquiring about sexual dysfunction among their patients. It should be noted that some researchers [13-18] included iatrogenic endocrine disorders (amenorrhea, galactorrhea and gyne- 
Table 1 Classification of sexual dysfunctions in DSM IV TR.

\begin{tabular}{|c|c|c|c|c|c|c|}
\hline $\begin{array}{l}\text { Sexual Desire } \\
\text { Disorders }\end{array}$ & $\begin{array}{l}\text { Sexual Arousal } \\
\text { Disorders }\end{array}$ & Orgasmic Disorders & $\begin{array}{l}\text { Sexual Pain } \\
\text { Disorders }\end{array}$ & $\begin{array}{l}\text { Sexual Dysfunction } \\
\text { due to a General } \\
\text { Medical Condition }\end{array}$ & $\begin{array}{l}\text { Substance In- } \\
\text { duced Sexual } \\
\text { Dysfunction }\end{array}$ & $\begin{array}{l}\text { Sexual Dysfunction } \\
\text { not Otherwise } \\
\text { Specified }\end{array}$ \\
\hline $\begin{array}{l}\text { - hypoactive sexual } \\
\text { desire disorder } \\
\text { - sexual aversion } \\
\text { disorder }\end{array}$ & $\begin{array}{l}\text { - female sexual } \\
\text { arousal disorder } \\
\text { - male erectile } \\
\text { disorder }\end{array}$ & $\begin{array}{l}\text { - female orgasmic disorder } \\
\text { - male orgasmic disorder } \\
\text { - premature ejaculation }\end{array}$ & $\begin{array}{l}\text { - dyspareunia } \\
\text { - vaginismus }\end{array}$ & & & \\
\hline
\end{tabular}

comastia) in their definition of sexual dysfunction which is not in keeping with international classifications (ICD-10, DSM-IVTR), and which may therefore have affected the data on prevalence rates.

Also, the definition of sexual dysfunction ( $\bullet$ Table 1 ) used by some investigators $[13,14,16,18]$ included only "decreased libido" and "impotence/sexual dysfunction", without considering other areas of sexual dysfunction. Despite this, psychiatrists frequently do not address issues relating to the sexual health of their patients [9,19-23] and they are uncomfortable [24] or reluctant to discuss this subject $[3,22]$ with the result that the prevalence of sexual dysfunction is underestimated [14,23,2528]. Sexual side effects however, increase the risk of inadequate compliance or discontinuation of drug therapy: in fact, they are one of the most important factors associated with poor compliance with treatment [29-37].

The burden of sexual dysfunction is not only relevant to drug compliance: sexual functioning impacts significantly on quality of life. Sexual dysfunction secondary to the use of antipsychotics can adversely affect quality of life and therefore is an important outcome measure of treatment.

The data on antipsychotic-induced sexual dysfunction tend to show high and variable prevalence rates. Baggaley [30] identified that between $30 \%$ and $80 \%$ of female schizophrenic patients and between $45 \%$ and $80 \%$ of male schizophrenic patients reported impaired sexual functioning. Other studies have documented much higher rates: for example those of Macdonald et al. [38] (82\% of men and $96 \%$ of women) and Fan et al. [39] (between $65 \%$ and $94 \%$ for both sexes, depending on the different scales used). Other studies have reported lower rates: approximately $58 \%$ of men and $33 \%$ of women in the study by Ghadirian et al. [40], $59.3 \%$ of men and $49.1 \%$ of women in the study by Fujii et al. [41] while only $10 \%$ (for both sexes) in the research by Knegtering et al. [42].

The variation in prevalence rates is related to several factors, but is mainly due to the different methodological approaches adopted by different studies: studies that relied only on spontaneous reporting of side effects, report low rates of sexual dysfunction, while studies using structured interviews or questionnaires show higher rates of sexual dysfunction $[3,11,12]$.

It should be noted that some researchers [13-18] included iatrogenic endocrine disorders (amenorrhea, galactorea and gynecomastia) in their definition of sexual dysfunction which is not in keeping with international classifications (ICD-10, DSM-IV-TR), and which may therefore have affected the data on prevalence rates. Also, the definition of sexual dysfunction used by some investigators $[13,14,16,18]$ only included "decreased libido" and "impotence/sexual dysfunction", without considering other areas of sexual dysfunction.
Table 2 Probable mechanisms of action of antipsychotic-induced sexual dysfunction (from Baggaley [30]; Compton [20]; Haddad and Wieck [44]; Knegtering et al. $2003[3,45])$.

\begin{tabular}{|c|c|c|}
\hline Drug effect & Physiological effect & $\begin{array}{l}\text { Sexual function } \\
\text { effect }\end{array}$ \\
\hline $\begin{array}{l}\text { dopamine receptor } \\
\text { antagonism }\end{array}$ & $\begin{array}{l}\text { inhibition of motiva- } \\
\text { tion and reward }\end{array}$ & decreased desire \\
\hline $\begin{array}{l}\text { dopamine D2 receptor } \\
\text { antagonism (tuberoin- } \\
\text { fundibular pathway) }\end{array}$ & hyperprolactinemia & $\begin{array}{l}\text { decreased desire, } \\
\text { impaired arousal, } \\
\text { impaired orgasm }\end{array}$ \\
\hline $\begin{array}{l}\text { histamine receptor } \\
\text { antagonism }\end{array}$ & sedation & impaired arousal \\
\hline $\begin{array}{l}\text { cholinergic receptor } \\
\text { antagonism }\end{array}$ & $\begin{array}{l}\text { reduced peripheral } \\
\text { vasodilation }\end{array}$ & erectile dysfunction \\
\hline $\begin{array}{l}\alpha \text {-adrenergic } \alpha \text { recep- } \\
\text { tor antagonism }\end{array}$ & $\begin{array}{l}\text { reduced peripheral } \\
\text { vasodilation }\end{array}$ & $\begin{array}{l}\text { priapism, decreased } \\
\text { erection/lubrification, } \\
\text { abnormal ejaculation }\end{array}$ \\
\hline
\end{tabular}

\section{Mechanism of action of antipsychotics on sexual function}

Antipsychotic drugs exert numerous different actions on cell receptors in the central nervous system (CNS). They can also cause endocrine disturbances by increasing prolactin.

Different hypotheses have been suggested for the mechanism of action of antipsychotics on sexual function ( $\bullet$ Table 2 ), including $[3,20,23,30,43-47]$ : (i) dopaminergic antagonist action, (ii) increased prolactin (secondary to dopaminergic antagonist action), (iii) blockage of alpha-adrenergic receptor (antiadrenergic action), (iv) blockage of acetylcholine receptors (anticholinergic action), (v) serotonin antagonist action, (vi) histamine antagonist action.

Binding to dopaminergic, cholinergic, histaminergic and $\alpha$-adrenergic receptors may directly affect sexual function by inhibiting motivation and reward, increasing sedation and reducing peripheral vasodilation $[3,25,30,44,45]$.

Sthal [48] suggests that the neurotransmitters involved in the 3 stages (desire, arousal and orgasm) of the human sexual response cycle have different mechanisms of action. For example, in stage 1 (desire), dopamine (DA) exerts a positive influence, while serotonin (5HT) has negative effects. In stage 2 , several neurotransmitters facilitate sexual arousal, including norepinephrine (NE), acetylcholine (Ach), and dopamine (DA). As with desire, serotonin has a negative effect. Stage 3 (orgasm), is inhibited by serotonin and facilitated by norepinephrine; dopamine may have weak positive influences.

However, the exact nature of involvement of the various neurotransmitters in antipsychotic induced sexual dysfunction remains unclear.

Differences in receptor-affinity profiles of antipsychotics may help explain the differences in their sexual side-effect profiles [49]. For example, antipsychotics with $\alpha$-adrenergic antagonis- 
tic properties are associated with priapism [50]. Although antipsychotics can induce relatively isolated effects on the neurotransmitters involved in the response cycle, the mechanism of action leading to sexual dysfunction is more complex. Sexual side effects often occur in combination, and pharmacological effects on one component may have an indirect effect on another area of sexual functioning. Furthermore, the etiology of sexual dysfunction may in many cases be multifactorial [2].

Hyperprolactinemia is caused by blockage of dopamine D2 receptors in the hypothalamic infundibular system [51-55]. Dopamine (DA) has an antagonistic effect on the production of prolactin (one of the hormones most implicated in sexual response). Hence, the use of antipsychotics can lead to a decrease in dopamine and a consequent rise in prolactin, which can inhibit sexual function.

Sexual dysfunction is most prevalent in patients with hyperprolactinemia; a correlation between antipsychotic-induced hyperprolactinemia and sexual dysfunction rates has also been documented $[2,3,5,20,26,30,44,51,56-61]$. This correlation, however, is neither confirmed $[15,62-67]$ nor clear $[68,69]$ in other studies. There have also been reported cases of sexual dysfunction with normal prolactin levels [70,71]: in these cases, the sexual dysfunction was probably associated with other physical (e.g., diabetes) or psychological (e. g., quality of partner relationship) factors.

It is unclear whether sexual dysfunction correlates to a direct effect and/or an indirect effect of hyperprolactinemia. Increased prolactin levels, inhibit the hypothalamic release of $\mathrm{GnRH}$ (gonadotropin releasing hormone), a hormone that releases gonadotropins, follicle stimulating hormone (FSH) and luteinizing hormone (FSH) from the anterior pituitary gland. The end result of an increase in prolactin, may therefore consist of a reduction in levels of gonadal hormones (e. g., decreased levels of estrogen in women and testosterone in men) $[9,44,72]$. During long-term treatment with typical antipsychotics, it is reported that women have significantly more elevated prolactin levels than men [73]. Increased prolactin levels are also more common among women $[3,74]$. Smith et al. [75], for example, found that after 2 years on antipsychotics medication, $75 \%$ of women and $34 \%$ of men had high levels of prolactin.

An increase in prolactin is very common among psychotic patients treated with a first generation antipsychotic, but also with risperidone and amisulpride $[3,23,59,76,77]$.

Based on these observations, some authors make the distinction between antipsychotics that elevate prolactin levels (so-called "prolactin-raising") and those that have minimal and/or transient effects on prolactin levels ("prolactin-sparing") (○ Table 3) $[59,72,78,79]$.

It is worth highlighting that hyperprolactinemia is not always accompanied by clinical symptoms (such as amenorrhea, or gynecomastia) [73].

In addition to direct pharmacological effects (such as, for example, the antagonistic action on dopamine receptors) and endocrine dysfunction, other pharmacological side effects including sedation (mainly related to antihistaminergic action), extrapyramidal effects and weight gain, can indirectly reduce sexual desire [85].

It is difficult to evaluate the effects of antipsychotic drugs on sexual function in patients with schizophrenia because they are often superimposed on sexual impairment caused by the disease itself [25]. In a comparison group study comparing schizophrenic patients on antipsychotic medication with schizophrenic
Table 3 Prolactin and antipsychotics (from Baggaley [30], Maguire [54]; Montejo [59]; Montgomery et al. [84]).

\begin{tabular}{|c|c|c|}
\hline & Prolactin-raising & prolactin-sparing \\
\hline amisulpride & - & \\
\hline aripiprazole & & (;) \\
\hline asenapine & $?$ & $?$ \\
\hline clozapine & & (;) \\
\hline haloperidol & () & \\
\hline iloperidone & $?$ & $?$ \\
\hline lurasidone & $?$ & $?$ \\
\hline olanzapine & & (-) \\
\hline paliperidone & $\odot$ & \\
\hline quetiapine & & (-) \\
\hline risperidone & (-) & \\
\hline ziprasidone & & (-) \\
\hline other typical antipsychotics & (อ) & \\
\hline
\end{tabular}

patients taking no medication and healthy individuals with no schizophrenia, there was a high rate of sexual dysfunction in both patient groups [86].

\section{Antipsychotics and sexual dysfunction}

Antipsychotic-induced side effects on sexual function are usually inhibitory in nature and may affect all phases of the sexual response cycle.

These effects include decreased sexual desire ("libido"), difficulties with erection, achieving orgasm and sexual satisfaction, as well as ejaculation disorders (delayed or inhibited ejaculation, retrograde ejaculation, spontaneous ejaculation in the absence of sexual stimulation, decreased ejaculatory volume) $[20,72,85,87,88]$.

Data from the early literature generally showed that (i) all antipsychotics are associated with decreased sexual desire [89]. (ii) Most antipsychotics are associated with erectile dysfunction. Those most frequently cited in the literature include: chlorpromazine, pimozide, thioridazine, thiotixene and sulpiride [90]. (iii) Thioridazine was probably one of the first antipsychotic drugs identified as having the ability to cause delayed ejaculation [90]. (iv) There are many case reports on antipsychoticinduced anorgasmia: among these, the most frequently cited antipsychotic is thioridazine [89], followed by trifluoperazine [91]. (v) Priapism is a possible side effect of all antipsychotic drugs [92], particularly for phenothiazines (chlorpromazine, fluphenazine and thioridazine), although more recently isolated cases have been reported with aripiprazole [93], clozapine, flupenthixol [89], olanzapine, quetiapine [94,95], risperidone [25] and ziprasidone [95-97].

To date, most of the studies conducted have been observational comparison studies of various typical and atypical antipsychotic drugs. The number of randomized controlled trials that specifically focus on antipsychotic induced sexual dysfunction is small [4].

The interpretation of data relating to the assessment of sexual functioning is complex because of the different assessment tools and study methods adopted in the various studies, making it difficult to compare findings. The conclusions reached by the various researchers as summarized below, are not definitive and they are difficult to interpret and need to be confirmed by further studies [98-100]. 
In this review we have provided a summary of the main conclusions reached by studies in the current literature, as well as summarizing the most salient information on individual drugs.

Serretti et al. [11], in a recent meta-analysis (which included data on studies investigating sexual dysfunction related to treatment with antipsychotics) showed that quetiapine, ziprasidone, perphenazine and aripiprazole were associated with relatively low rates of sexual dysfunction (16-27\%), whereas olanzapine, risperidone, haloperidol, clozapine and thioridazine were associated with higher rates of sexual dysfunction (40-60\%).

In the randomized double-blind study by Kelly et al. [101] (with a sample size of only 27 patients) the side effects of fluphenazine, quetiapine and risperidone were compared. Patients experienced high rates of sexual dysfunction with each of these drugs ( $78 \%$ with fluphenazine, $50 \%$ with quetiapine, and $42 \%$ with risperidone). Symptom improvement, mainly with regards to arousal/erection, was observed during the trial only in those patients treated with quetiapine. The authors concluded that quetiapine has a better side effect profile than the other two drugs. In a randomized open label comparison study by Knegtering et al. [102] (comparing the atypical antipsychotics, risperidone and olanzapine), 46 patients initially taking a typical antipsychotic, were switched to risperidone or olanzapine. Olanzepine was found to cause less sexual dysfunction.

In a study on 199 patients using combined data from an open and combined study, Knegtering et al. [3] concluded that typical antipsychotics and risperidone (considered to be prolactinraising) are associated with higher rates of sexual dysfunction (decreased libido, problems with orgasm) compared to prolactin-sparing antipsychotics (clozapine, olanzapine, quetiapine and sertindole).

In an observational study by Bobes et al. [103] conducted in Spain on 636 patients, lower rates of sexual dysfunction were found with quetiapine (18\%) compared to olanzapine (35\%), haloperidol (38\%) and risperidone (43\%).

In another observational study by Uçok et al. [104] conducted on 827 stable patients, it was reported that over $50 \%$ of patients experienced sexual dysfunction. Patients receiving poly-pharmacy experienced more severe side effects than those taking a single second-generation antipsychotic.

In the study by Nakonezny et al. [105] (conducted on a sample of 22 men) a switch from risperidone to quetiapine was not associated with any improvement in sexual function, assessed using a 5 item questionnaire.

Byerly et al. [106] using adjusted average ASEX (Arizona Sexual Experience Scale) rating scale scores, reported less severe sexual dysfunction with quetiapine compared to olanzapine and risperidone: however, these differences, were not clinically significant. Nagaraj et al. [107] also found no statistically significant differences in sexual dysfunction induced by risperidone, olanzapine and quetiapine: in this study, sexual function was measured using the SFQ (Sexual Functioning Questionnaire), which revealed a reduction in overall sexual functioning in $96 \%$ of cases for risperidone, $90 \%$ for olanzapine and $88 \%$ for quetiapine.

Another study by Byerly et al. [108] did not show any statistically significant difference in sexual functioning (as assessed by ASEX) after switching from risperidone to quetiapine.

Dossenbach et al. [31] conducted an observational study on 3838 patients. Sexual problems were common among all patients taking antipsychotic drugs, although there were no sta- tistically significant differences in prevalence: haloperidol (71\%), risperidone (68\%), quetiapine (60\%), olanzapine (56\%). In an observational study by Strouse et al. [109], conducted over only 12 weeks, comparing risperidone, olanzapine and clozapine, a worsening of sexual performance was reported in men only for each of these 3 drugs.

A study by Bitter et al. [110] showed a mild improvement in sexual function with olanzapine (compared to risperidone), which however was limited to libido.

In a study by Mahmoud et al. [111], it was reported that sexual functioning (as measured by the SR-DISF: Derogatis Interview for Sexual Function) of 42 schizophrenics improved after a switch from typical to atypical antipsychotics (amisulpride, olanzapine, quetiapine and risperidone) in spite of the fact that two of the atypical antipsychotic drugs prescribed (amisulpride and risperidone) are noted for their capacity to induce sexual dysfunction.

Montejo et al. [112] conducted an observational cross-sectional study on a sample of 243 patients with a diagnosis of psychotic disorder and found (using the PRSexDQ-SalSex) that $46 \%$ of patients experienced sexual dysfunction, among whom those treated with risperidone and typical antipsychotics had a significantly increased risk of sexual dysfunction. In the $\bullet$ Table 4 we have summarized the effect of individual antipsychotic drugs on sexual dysfunction (SD).

\section{Treatment of sexual dysfunction induced by antipsychotics}

Some recommended treatment approaches for the management of sexual dysfunction induced by antipsychotic drugs include the following: (i) A thorough clinical evaluation, to exclude comorbid conditions (physical and psychiatric) or sexual dysfunction secondary to alcohol or illicit drug use or other prescribed medication. The assessment should include measurement of serum prolactin in patients presenting with side effects suggestive of hyperprolactinemia $[2,74]$. (ii) Modification of risk factors (where possible, avoid use of other drugs associated with sexual dysfunction, smoking cessation, abstinence from alcohol and illicit drugs, maintaining normal blood sugar levels in diabetic patients, treatment of hypertension and hypercholesterolemia). (iii) In the early phase of treatment, if possible, consider waiting for a spontaneous improvement in side effects [63]. (iv) Reduction in dose of antipsychotic drug responsible for side effects. (v) Switch to another antipsychotic drug with a more tolerable side effect profile (ideally to a "prolactin-sparing" antipsychotic) [59]. (vi) Addition of symptom targeted therapy - using dopaminergic drugs (amantadine, bromocriptine, cabergoline) or drugs with specific effects on sexual functioning (such as phosphodiesterase inhibitors or yohimbine) $[1,2,5$, $23,72,140,141]$. In a study by Inder et al., selegiline was not found to alleviate symptoms of antipsychotic-induced sexual dysfunction [142]. Sildenafil may be a useful option in the treatment of antipsychotic-induced sexual dysfunction in men [141]. In general, the evidence supporting the addition of symptomatic therapies is weak $[1,2,143]$.

\section{Conclusions}

$\nabla$

All antipsychotics drugs can cause sexual dysfunction, although it is extremely difficult to accurately determine the true prevalence. This review confirms that antipsychotic-induced sexual 


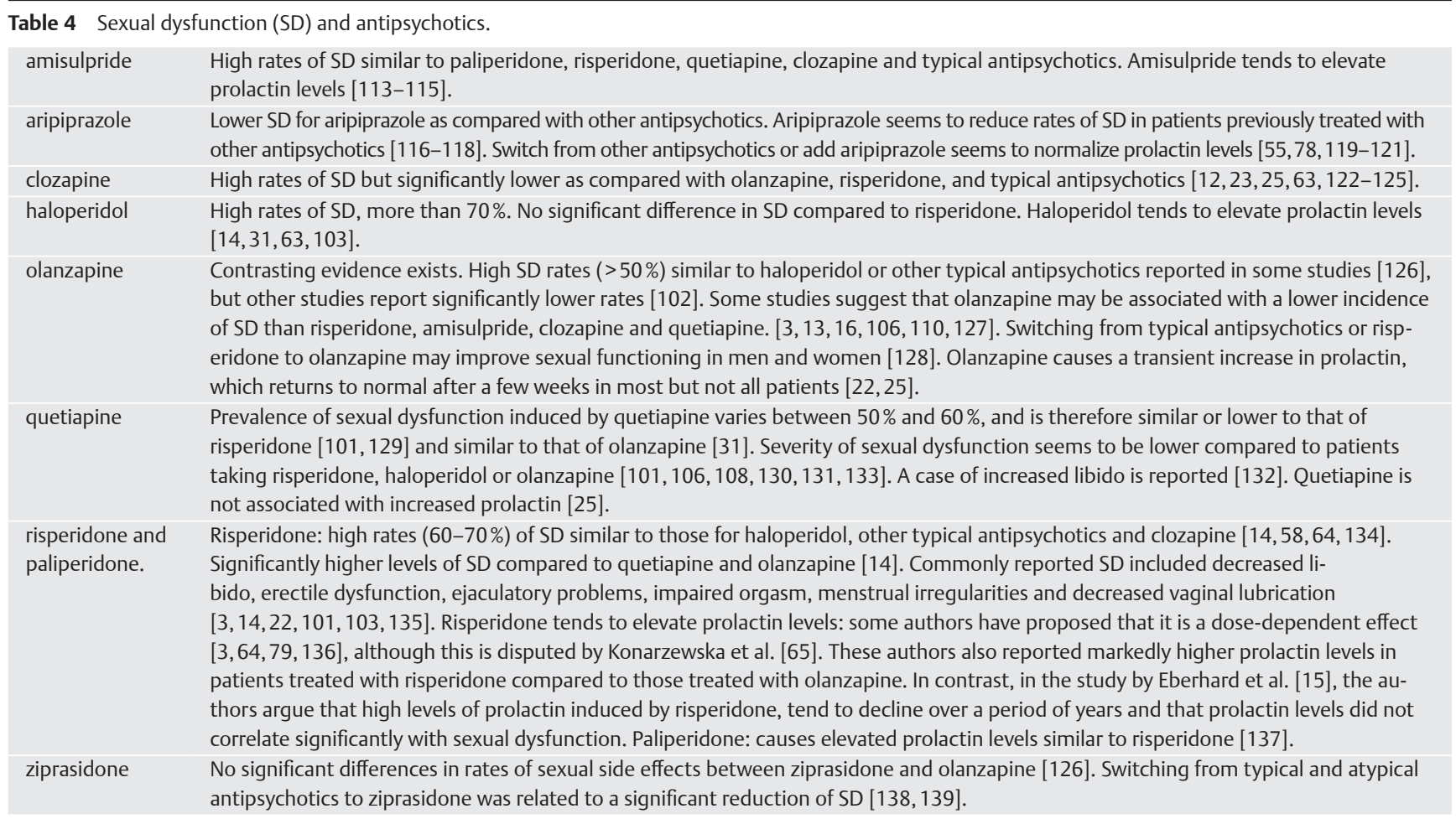

dysfunction is common among patients taking antipsychotic medication.

The conclusions reached by the different researchers are not definitive and are difficult to interpret mainly because of the significant differences in methods used for assessing sexual function: further studies are needed on the underlying causes and types of sexual dysfunction, and on the factors linking antipsychotic use and sexual dysfunction, in particular with regard to the specific mechanisms of action including alterations in prolactin levels and binding to dopaminergic, histaminergic, cholinergic, serotoninergic and $\alpha$-adrenergic receptors.

Some evidence suggests that second-generation antipsychotics (with some exceptions, for example, risperidone) seem to have a better sexual side effect profile compared to traditional first generation antipsychotics.

The impact of antipsychotic-induced sexual dysfunction negatively affects quality of life; it has potential implications for patient adherence to medication and the success of antipsychotic treatment. Antipsychotic-induced sexual dysfunction adversely affects compliance, and is one of the factors that must be taken into account when selecting treatment. Further well designed randomized control trials, investigating the effectiveness of different strategies of managing antipsychotic-induced sexual dysfunction are needed [144-146].

\section{Conflict of Interest}

$\nabla$

The authors declare no conflicts of interest.

\footnotetext{
References

1 Berner MM, Hagen M, Kriston L et al. Management of sexual dysfunction due to antipsychotics drug therapy. Cochrane Database of Systematic Reviews 2007; 1-24 doi:10.1002/14651858.CD003546.pub2

2 Compton MT, Miller AH. Antipsychotic-induced hyperprolactinemia and sexual dysfunction. Psychopharmacol Bull 2002; 36: 143-164
}

3 Knegtering H, Van den Moolen AEGM, Castelein S et al. What are the effects of antipsychotics on sexual dysfunction and endocrine functioning? Psychoneuroendocrinology 2003; 28: 109-123

4 Labbate LA. Psychotropics and sexual dysfunction: the evidence and treatments. Adv Psychosom Med 2008; 29: 107-130

5 Gitlin M. Sexual dysfunction with psychotropic drugs. Expert Opin Pharmacother 2003; 4: 2259-2269

6 Tardieu S, Micallef J, Bonierbale M et al. Sexual behaviour in schizophrenic patients: the impact of antipsychotics. Encephale 2006; 32: 697-704

7 Akhtar S, Thompson JA Jr. Schizophrenia and sexuality: a review and a report of twelve unusual cases, part I. J Clin Psychiatry 1980; 41: 134-142

8 Akhtar S, Thompson JA Jr. Schizophrenia and sexuality: a review and a report of twelve unusual cases, part II. J Clin Psychiatry 1980; 41: 166-174

9 Peuskens J, Sienaert P, De Hert M. Sexual dysfunction: the unspoken side effect of antipsychotics. Eur Psychiatry 1998; 13: 23s-30s

10 Dervaux A, El Omari F. Sexual dysfunction in schizophrenics patients, the role of antipsychotics. Presse Med 2005; 34: 529-532

11 Serretti A, Chiesa A. A meta-analysis of sexual dysfunction in psychiatric patients taking antipsychotics. Int Clin Psychopharmacol 2011; 26: $130-140$

12 Serretti A, Chiesa A. Sexual side effects of pharmacological treatment of psychiatric diseases. Clin Pharmacol Ther 2011; 89: 142-147

13 Brugnoli $R$, Novick $D$, Belger $M$ et al. Effectiveness of antipsychotic treatment for schizophrenia: Italian results of the pan-European Schizophrenia Outpatient Health Outcomes (SOHO) study after 12 months. Giornale Italiano di Psicopatologia 2006; 12: 283-292

14 Dossenbach M, Erol A, el Mahfoud Kessaci $M$ et al. Effectiveness of antipsychotic treatments for schizophrenia: interim 6-month analysis from a prospective observational study (IC-SOHO) comparing olanzapine, quetiapine, risperidone, and haloperidol. IC-SOHO Study Group. J Clin Psychiatry 2004; 65: 312-321

15 Eberhard J, Lindström E, Holstad $M$ et al. Prolactin level durin 5 years of risperidone treatment in patients with psychotic disorders. Acta Psychiatr Scand 2007; 115: 268-276

16 Haro JM, Salvador-Carulla L. The SOHO (Schizophrenia Outpatient Health Outcome) study. Implications for the treatment of schizophrenia. CNS Drugs 2006; 20: 293-301

17 Mullen B, Brar JS, Vagnucci AH et al. Frequency of sexual dysfunction in patients with schizophrenia on haloperidol, clozapine, or risperidone. Schizophr Res 2001; 48: 155-158 
18 Treuer T, Anders M, Bitter I et al. Effectiveness and tolerability of schizophrenia treatment in central and eastern Europe: results after 1 year from a prospective, observational study (IC-SOHO). Int J Psychiatr Clin Pract 2006; 10: 78-90

19 Assalian P, Fraser R, Tempier $R$ et al. Sexuality and quality of life of patients with schizophrenia. Int J Psychiatr Clin Pract 2000; 4: 29-33

20 Compton MT, Miller AH. Sexual side effects associated with conventional and atypical antipsychotics. Psychopharmacol Bull 2001; 35 : 89-108

21 Higgins A, Barker P, Begley CM. Neuroleptic medication and sexuality: the forgotten aspect of education and care. J Psychiatr Ment Health Nurs 2005; 12: 439-446

22 Kelly DL, Conley RR. Sexuality and schizophrenia: a review. Schizophr Bull 2004; 30: 767-779

23 Murthy S, Wylie K. Sexual problems in patients on antipsychotic medication. Sex Relation Ther 2007; 22: 97-107

24 Lukoff D, Gioia-Hasick D, Sullivan $G$ et al. Sex education and rehabilitation with schizophrenic male outpatients. Schizophr Bull 1986; 12: 669-677

25 Cutler AJ. Sexual dysfunction and antipsychotics treatment. Psychoneuroendocrinology 2003; 28: 69-82

26 Dossenbach $M$, Hodge A, Anders $M$ et al. Prevalence of sexual dysfunction in patients with schizophrenia: international variation and underestimation. Int J Neuropsychopharmacol 2005; 8: 195-201

27 Fortier P, Mottard JP, Trudel G et al. Study of sexuality-related characteristics in young adults with schizophrenia treated with novel neuroleptics and in a comparison group of young adults. Schizophr Bull 2003; 29: 559-572

28 Nnaji RN, Friedman T. Sexual dysfunction and schizophrenia: psychiatrist' attitudes and training needs. Psychiatric Bull 2008; 32: 208-210

29 Apantaku-Olajide T, Gibbons P, Higgins A. Drug-induced sexual dysfunction and mental health patients' attitude to psychotropic medications. Sex Relation Ther 2011; 26: 145-155

30 Baggaley M. Sexual dysfunction in schizophrenia: focus on recent evidence. Hum Psychopharmacol 2008; 23: 201-209

31 Dossenbach M, Dyachkova Y, Pirildar S et al. Effects of atypical and typical antypsichotic treatments on sexual function in patients with schizophrenia: 12-month results from the Intercontinental Schizophrenia Outpatients Health Outcomes (IC-SOHO) study. Eur Psychiatry 2006; 21: 251-258

32 Hamer S, Haddad PM. Adverse effects of antipsychotics as outcome measures. Br J Psychiatry 2007; 191: s64-s70

33 Kelly DL, Conley RR. Evaluating sexual function in patients with treatment-resistant schizophrenia. Schizophr Res 2003; 63: 195-196

34 Khawaja MY. Sexual dysfunction in male patients taking antipsychotics. J Ayub Med Coll Abbottabad 2005; 17: 73-75

35 Lambert $M$, Conus $P$, Eide $P$ et al. Impact of present and past antipsychotic side effects on attitude toward typical antipsychotic treatment and adherence. Eur Psychiatry 2004; 19: 415-422

36 Rosenberg KP, Bleiberg KL, Koscis J et al. A survey of sexual side effects among severely mentally ill patients taking psychotropic medications: impact on compliance. J Sex Marital Ther 2003; 29: 289-296

37 Smith SM, O'Keane V, Murray R. Sexual dysfunction in patients taking conventional antipsychotic medication. Br J Psychiatry 2002; 181: 49-55

38 Macdonald S, Halliday J, MacEwan T et al. Nithsdale schizophrenia surveys 24: sexual dysfunction. Case-control study. Br J Psychiatry 2003; 182: 50-56

39 Fan X, Henderson DC, Chiang E et al. Sexual functioning, psychopatology and quality of life in patients with schizophrenia. Schizophr Res 2007; 94: 119-127

40 Ghadirian AM, Chouinard G, Annable L. Sexual dysfunction and plasma prolactin levels in neuroleptic-treated schizophrenic outpatients. J Nerv Ment Dis 1982; 170: 453-467

41 Fujii A, Yasui-Furukori N, Sugawara $N$ et al. Sexual dysfunction in Japanese patients with schizophrenia treated with antipsychotics. Prog Neuropsychopharmacol Biol Psychiatry 2010; 34: 288-293

42 Knegtering H, Blijd C, Boks MPM. Sexual dysfunction and prolactin levels in patients using classical antipsychotics, risperidone or olanzapine. Schizophr Res 1999; 36: 355-356

43 Haddad PM, Sharma SG. Adverse effects of atypical antipsychotics: differential risk and clinical implications. CNS Drugs 2007; 21: 911-936

44 Haddad PM, Wieck A. Antipsychotic-induced hyperprolactinaemia. Mechanisms, clinical features and management. Drugs 2004; 64: $2291-2314$
45 Knegtering $H$. Antipsychotic treatment and sexual functioning, the role of prolactin. University of Groningen; The Netherlands: 2003 Available on line at http://irs.ub.rug.nl/ppn/254939104

46 Knegtering $H$, Bruggeman $R$. What are the effects of antipsychotics on sexual functioning? Prim Psychiatry 2007; 14: 51-56

47 Westheide J, Cohen S, Bender S et al. Sexual dysfunction in psychiatric inpatients the role of antipsychotic medication. Pharmacopsychiatry 2007; 40: 140-145

48 Stahl SM. Stahl's Essential Psychopharmacology: Neuroscientific Basis and Practical Applications. (third edition). New York: Cambridge University Press; 2008

49 Nasrallah HA. Atypical antipsychotic-induced metabolic side effects: insights from receptor-binding profiles. Mol Psychiatry 2008; 13: 27-35

50 Andersohn F, Schmedt N, Weinmann S et al. Priapism associated with antipsychotics: role of alpha1 adrenoceptor affinity. J Clin Psychopharmacol 2010; 30: 68-71

51 Bhuvaneswar CG, Baldessarini RJ, Harsh VL et al. Adverse endocrine and metabolic effects of psychotropic drugs. CNS Drugs 2009; 23: 1003-1021

52 Goodnick PJ, Rodriguez L, Santana O. Antipsychotics: impact on prolactin levels. Exp Opin Pharm 2002; 3: 1381-1391

53 Madhusoodanan S, Parida S, Jimenez C. Hyperprolactinemia associated with psychotropics. A review. Hum Psychopharmacol Clin Exp 2010; 25: 281-297

54 Maguire GA. Prolactin elevation with antipsychotic medications: mechanisms of action and clinical consequences. J Clin Psychiatry 2002; 63: 56-62

55 Potkin SG, Saha AR, Kujawa MJ et al. Aripiprazole, an antipsychotic with a novel mechanism of action, and risperidone vs placebo in patients with schizophrenia and schizoaffective disorder. Arch Gen Psychiatry 2003; 60: 681-690

56 Conley RR, Kelly DL. Second-generation antipsychotics for schizophrenia: a review of clinical pharmacology and medication-associated side effects. Isr J Psychiatry Relat Sci 2005; 42: 51-60

57 Hummer M, Huber J. Hyperprolactinaemia and antipsychotic therapy in schizophrenia. Curr Med Res Opin 2004; 20: 189-197

58 Liu-Seifert H, Kinon BJ, Tennant CJ et al. Sexual dysfunction in patients with schizophrenia treated with conventional antipsychotics or risperidone. Neuropsychiatr Dis Treat 2009; 5: 47-54

59 Montejo AL. Prolactin awareness: an essential consideration for physical health in schizophrenia. Eur Neuropsychopharmacol 2008; 18 : S $108-S 114$

60 Rettenbacher MA, Hofer A, Ebenbichler $C$ et al. Prolactin levels and sexual adverse effects in patients with schizophrenia during antipsychotic treatment. J Clin Psychopharmacol 2010; 30: 711-715

61 Smith SM. The impact of hyperprolactinaemia on sexual function in patients with psychosis. J Psychopharmacol 2008; 22: 63-69

62 Howes OD, Wheeler MJ, Pilowsky LS et al. Sexual function and gonadal hormones in patients taking antipsychotic treatment for schizophrenia or schizoaffective disorder. J Clin Psychiatry 2007; 68: 361-367

63 Hummer M, Kemmler G, Kurz M et al. Sexual disturbances during clozapine and haloperidol treatment for schizophrenia. Am J Psychiatry 1999; 156: 631-633

64 Kleinberg DL, Davis JM, de Coster R et al. Prolactin levels and adverse events in patients treated with risperidone. J Clin Psychoharmacol 1999; 19: 57-61

65 Konarzewska B, Wolczyński S, Szulc A et al. Effect of risperidone and olanzapine on reproductive hormones, psychopathology and sexual functioning in male patients with schizophrenia. Psychoneuroendocrinology 2009; 34: 129-139

66 Johnsen E, Kroken R, Loberg EM et al. Sexual dysfunction and hyperprolactinemia in male psychotic inpatients: a cross-sectional study. Adv Urol 2011 article ID 686924

67 Yasui-Furukori N, Fujii A, Sugawara $N$ et al. No association between hormonal abnormality and sexual dysfunction in Japanese schizophrenia patients treated with antipsychotics. Hum Psychopharmacol 2012; 27: 82-89

68 Knegtering H, Van den Bosch $R$, Castelein $S$ et al. Are sexual side effects of prolactin-raising antipsychotics reducible to serum prolactin? Psychoneuroendocrinology 2008; 33: 711-717

69 Westheide I, Cvetanovska G, Albrecht $C$ et al. Prolactin, subjective well-being and sexual dysfunction: an open label observational study comparing quetiapine with risperidone. J Sex Med 2008; 5: 2816-2826

70 Istikoglou C, Vlissides D, Michelidakis $K$ et al. Quality of life: sexual dysfunction in young people with schizophrenia treated with ziprasidone. Eur Neuropsychopharm 2009; 19: S511 
71 Van Bruggen M, Van Amelsvoort T, Wouters L et al. Sexual dysfunction and hormonal changes in first episode psychosis patients on olanzapine or risperidone. Psychoneuroendocrinology 2009; 34: 989-995

72 Dickson RA, Glazer WM. Neuroleptic-induced hyperprolactinemia. Schizophr Res 1999; 35: S75-S86

73 Wieck A, Haddad M. Antipsychotic-induced hyperprolactinaemia in women: pathophysiology, severity and consequences. Selective literature review. Br J Psychiatry 2003; 182: 199-204

74 Marder SR, Essock SM, Miller AL et al. Physical health monitoring of patients with schizophrenia. Am J Psychiatry 2004; 161: 1334-1349

75 Smith S, Wheeler MJ, Murray $R$ et al. The effects of antipsychoticinduced hyperprolactinaemia on the hypotalamic-pituitary-gonadal axis. J Clin Psychopharmacol 2002; 22: 109-114

76 American Psychiatric Association. Practise guidelines for the treatment of patients with schizophrenia. Second edition. April 2004. Available on line at http://www.psychiatryonline.com/pracGuide/ pracGuideTopic_6.aspx

77 Conley RR, Mahmoud $R$. A randomized double-blind study of risperidone and olanzapine in the treatment of schizophrenia or schizoaffective disorder. Am J Psychiatry 2001; 158: 765-774

78 Chrzanowski WK, Marcus RN, Torbeyns A et al. Effectiveness of longterm aripripazole therapy in patients with acutely relapsing or chronic, stable schizophrenia: a 52-week, open-label comparison with olanzapine. Psychopharmacology 2006; 189: 259-266

79 Volavka J, Czobor P, Cooper TB et al. Prolactin levels in schizophrenia and schizoaffective disorder patients treated with clozapine, olanzapine, risperidone, or haloperidol. J Clin Psychiatry 2004; 65: 57-61

80 Potkin SG. Asenapine: a critical overview. J Clin Psychiatry 2011; 72: 14-18

81 Weber J, McCormack PL. Asenapine. CNS Drugs 2009; 23: 781-792

82 Citrome L. Iloperidone: a critical overview. J Clin Psychiatry 2011; 72: 19-23

83 Kane L. Lurasidone: a critical overview. J Clin Psychiatry 2011; 72: 24-28

84 Montgomery J, Winterbottom E, Jessani M et al. Prevalence of hyperprolactinemia in schizophrenia: association with typical and atipical antipsychotic treatment. J Clin Psychiatry 2004; 65: 1492-1498

85 Baldwin D, Mayers A. Sexual side-effects of antidepressant and antipsychotic drug. Adv Psychiatric Treatment 2003; 9: 202-210

86 Aizenberg D, Zemishlany Z, Dorfman-Etrog $P$ et al. Sexual dysfunction in male schizophrenic patients. J Clin Psychiatry 1995; 56: 137-141

87 Boora K, Chiappone K, Dubovsky S et al. Ziprasidone-induced spontaneous orgasm. J Psychopharmacol 2010; 24: 947-948

88 Freeman SA. Iloperidone-induced retrograde ejaculation. Int Clin Psychopharmacol 2013, [Epub ahead of print] doi:10.1097/ YIC.0b013e32835e9112

89 Orazzo C, Bortolotti F, Monteleone P. Gli psicofarmaci e la funzionalità sessuale nella pratica clinica. Available on line at http://www. psychiatryonline.it/ital/riviste/quaderni/orazzo.htm (latest access on 18 february 2013)

90 Kotin J, Wilbert DE, Verburg D et al. Thioridazine and sexual dysfunction. Am J Psichiatry 1976; 133: 82-85

91 Degen $K$. Sexual dysfunction in women using major tranquilizers. Psychosomatics 1982; 23: 959-961

92 Compton MT, Miller AH. Priapism associated with conventional and atypical antipsychotic medications: a review. J Clin Psychiatry 2001; 62: 362-366

93 Mago R, Anolik $R$, Johnson RA et al. Recurrent priapism associated with use of aripiprazole. J Clin Psychiatry 2006; 67: 1471-1472

94 Penaskovic KM, Haq F, Raza S. Priapism during treatment with Olanzapine, Quetiapine, and Risperidone in a patient with schizophrenia: a case report. Prim Care Companion J Clin Psychiatry 2010; 12: PCC.09100939 doi:10.4088/PCC.09100939yel

95 Torun F, Yilmaz E, Gumus E. Priapism due to a single dose of quetiapine. Turk Psikiyatri Derg 2011; 22: 195-199

96 Kaufman KR, Stern L, Mohebati A et al. Ziprasidone-induced priapism requiring surgical treatment. Eur Psychiatry 2006; 21: 48-50

97 Reeves RR, Kimble R. Prolonged erections associated with ziprasidone treatment: a case report. J Clin Psychiatry 2003; 64: 97-98

98 Malik P. Sexual dysfunction in schizophrenia. Curr Opin Psychiatry 2007; 20: 138-142

99 Malik P. Sexual dysfunction in schizophrenia. Focus 2008; 6: 234-238

100 Rico-Villademoros F, Calandre EP. Antipsychotic-induced sexual dysfunction and the strength of the evidence. J Clin Psychiatry 2005; 66: 1074-1075
101 Kelly DL, Conley RR. A randomized double-blind 12-week study of quietapine, risperidone or fluphenazine on sexual functioning in people with schizophrenia. Psychoneuroendocrinology 2006; 31: 340-346

102 Knegtering $H$, Boks M, Blijd C et al. A randomized open-label comparison of the impact of olanzapine versus risperidone on sexual functioning. J Sex Marital Ther 2006; 32: 315-326

103 Bobes J, Garcia-Portilla MP, Rejas J et al. Frequency of sexual dysfunction and other reproductive side-effects in patients with schizophrenia treated with risperidone, olanzapine, quetiapine, or haloperidol: the results of the EIRE Study. J Sex Marital Ther 2003; 29: 125-147

104 Uçok A, Incensu C, Aker T et al. Sexual dysfunction in patients with schizophrenia on antipsychotic medication. Eur Psychiatry 2007; 22: 328-333

105 Nakonezny PA, Byerly MJ, Rush AJ. The relationship between serum prolactin level and sexual functioning among male outpatients with schizophrenia or schizoaffective disorder: a randomized doubleblind trial of risperidone vs. quetiapine. J Sex Marital Ther 2007; 33: 203-216

106 Byerly MJ, Nakonezny PA, Bettcher BM et al. Sexual dysfunction associated with second-generation antipsychotics in outpatients with schizophrenia or schizoaffective disorder: an empirical evaluation of olanzapine, risperidone, and quetiapine. Schizophr Res 2006; 86: 244-250

107 Nagaraj AK, Pai NB, Rao S. A comparative study of sexual dysfunction involving risperidone, quetiapine, and olanzapine. Indian J Psychiatry 2009; 51: 265-271

108 Byerly MJ, Nakonezny PA, Rush AJ. Sexual functioning associated with quetiapine switch vs. risperidone continuation in outpatients with schizophrenia or schizoaffective disorder: A randomized doubleblind pilot trial. Psychiatry Res 2008; 159: 115-120

109 Strous RD, Kupchik M, Roitman S et al. Comparison between risperidone, olanzapine, and clozapine in the management of chronic schizophrenia: a naturalistic prospective 12-week observational study. Hum Psychopharmacol 2006; 21: 235-243

110 Bitter I, Basson BR, Dossenbach MR. Antipsychotic treatment and sexual functioning in first-time neuroleptic-treated schizophrenic patients. Int Clin Psychopharmacol 2005; 20: 19-21

111 Mahmoud A, Hayhurst KP, Drake RJ et al. Second generation antipsychotics improve sexual dysfunction in schizophrenia: a randomised controlled trial. Schizophrenia Research and Treatment 2011, Article ID 596898 doi:10.1155/2011/596898

112 Montejo AL, Majadas S, Rico-Villademoros F et al. Frequency of sexual dysfunction in patients with a psychotic disorder receiving antipsychotics. J Sex Med 2010; 7: 3404-3413

113 Cookson J, Hodgson R, Wildgust HJ. Prolactin, hyperprolactinaemia and antipsychotic treatment: a review and lessons for treatment of early psychosis. J Psychopharmacol 2012; 26: 42-51

114 Paparrigopoulos T, Liappas J, Tzavellas E. Amisulpride-induced hyperprolactinemia is reversible following discontinuation. Prog Neuropsychoparmacol Biol Psychiatry 2007; 31: 92-96

115 Raj R, Sidhu BS. Hyperprolactinaemia with amisulpride. Indian J Psychiatry $2008 ; 5: 54-56$

116 Kerwin R, Millet B, Herman $E$ et al. A multicentre, randomized, naturalistic, open-label study between aripripazole and standard of care in the management of community-treated schizophrenic patients. Schizophrenia Trial of Aripripazole: (STAR) study. Eur Psychiatry 2007; 22: 433-443

117 Montejo AL, Campos MC, Fombellida C et al. Prospective, multicenter open-label, observational study of sexual function in patients beginning aripiprazole treatment. Eur Psychiatry 2008; 23: S133-S134

118 Mir A, Shivakumar K, Williamson RJ et al. Change in sexual dysfunction with aripiprazole: a switching or add-on study. J Psychopharmacol 2008; 22: 244-253

119 Casey DE, Carson WH, Saha AR et al. Switching patients to aripiprazole from other antipsychotic agents: a multicenter randomized study. Psychopharmacol 2003; 166: 391-399

120 Lee BH, Kim YK, Park SH. Using aripiprazole to resolve antipsychoticinduced symptomatic hyperprolactinemia: a pilot study. Prog Neuropsychopharmacol Biol Psychiatry 2006; 30: 714-717

121 Marder SR, McQuade RD, Stock E et al. Aripiprazole in the treatment of schizophrenia: safety and tolerability in short-term, placebocontrolled trials. Schizophr Res 2003; 61: 123-136

122 Aizenberg D, Modai I, Landa A et al. Comparison of sexual dysfunction in male schizophrenic patients maintained on treatment with classical antipsychotics versus clozapina. J Clin Psychiatry 2001; 62: 541-544 
123 Deschenes S, Courtois F, Lafond J. Potential side effects of clozapine on the sexual function of schizophrenic man. J Sex Educ Ther 2001; 26: 334-339

124 Breier AF, Malhotra AK, Su T-P et al. Clozapine and risperidone in chronic schizophrenia: effects on symptoms, Parkinsonian side effects, and neuroendocrine response. Am J Psychiatry 1999; 156: 294-298

125 Yusufi B, Mukherjee S, Flanagan R et al. Prevalence and nature of side effects during clozapine maintenance treatment and the relationship with clozapine dose and plasma concentration. Int Clin Psychopharmacol 2007; 22: 238-243

126 Grootens KP, Van Veelen NM, Peuskens J et al. Ziprasidone versus olanzapine in recent-onset schizophrenia and schizoaffective disorder: results of an 8-week double-blind randomized controlled trial. Schizophr Bull 2011; 37: 352-361

127 Costa AM, de Lima MS, Faria M et al. A naturalistic, 9-month followup, comparing olanzapine and conventional antipsychotics on sexual function and hormonal profile for males with schizophrenia. J Psychopharmacol 2007; 21: 165-170

128 Kinon BJ, Ahl J, Liu-Seifert H et al. Improvement in hyperprolactinemia and reproductive comorbidities in patients with schizophrenia switched from conventional antipsychotics or risperidone to olanzapine. Psychoneuroendocrinology 2006; 31: 577-588

129 Knegtering $R$, Castelein S, Bous H et al. A randomized open-label study of the impact of quetiapine versus risperidone on sexual functioning. J Clin Psychopharmacol 2004; 24: 56-61

130 Atmaca M, Kuloglu M, Tezcan E. A new atypical antipsychotic: quetiapine-induced sexual dysfunctions. Int J Imp Res 2005; 17: 201-203

131 Byerly MJ, Lescouflair E, Weber MT et al. An open-label trial of quetiapine for antipsychotic-induced sexual dysfunction. J Sex Marital Ther 2004; 30: 325-332

132 Menon A, Williams RH, Watson S. Increased libido associated with quietiapine. J Psychopharmacol 2006; 20: 125-127

133 Montejo González AL, Rico-Villademoros F, Tafalla M et al. A 6-month prospective observational study on the effects of quetiapina on sexual functioning. J Clin Psychopharmacol 2005; 25: 533-538

134 Wirshing DA, Pierre JM, Marder SR et al. Sexual side effects of novel antipsychotic medications. Schizophr Res 2002; 56: 25-30
135 Peuskens J. Risperidone in the treatment of patients with chronic schizophrenia: a multinational, multicentre, double-blind, parallelgroup study versus haloperidol. Br J Psychiatry 1995; 166: 712-726

136 David SR, Taylor CC, Kinon BJ et al. The effects of olanzapine, risperidone, and haloperidol on plasma prolactin levels in patients with schizophrenia. Clin Ther 2000; 22: 1085-1096

137 Berwaerts J, Cleton A, Rossenu S et al. A comparison of serum prolactin concentrations after administration of paliperidone extendedrelease and risperidone tablets in patients with schizophrenia. J Psychopharmacol 2010; 24: 1011-1018

138 Montejo AL, Rico-Villademoros F. Changes in sexual function for outpatients with schizophrenia or other psychotic disorders treated with ziprasidone in clinical practice settings: a 3-month prospective, observational study. J Clin Psychopharmacol 2008; 28: 568-570

139 Rossi A, Vita A, Tiradritti P et al. Assessment of clinical and metabolic status, and subjective well-being, in schizophrenic patients switched from typical and atypical antipsychotics to ziprasidone. Int Clin Psychopharmacol 2008; 23: 216-222

140 Duncan D, Taylor D. Treatment of psychotropic-induced hyperprolactinaemia. Psychiatric Bull 1995; 19: 755-757

141 Gopalakrishnan R, Jacob KS, Kuruvilla A et al. Sildenafil in the treatment of antipsychotic-induced erectile dysfunction: a randomized, double-blind, placebo-controlled, flexible-dose, two-way crossover trial. Am J Psychiatry 2006; 163: 494-499

142 Kodesh A, Weizman A, Aizenberg $D$ et al. Selegiline in the treatment of sexual dysfunction in schizophrenic patients maintained on neuroleptics: a pilot study. Clin Neuropharmacol 2003; 26: 193-195

143 Costa AM, Lima MS, Mari Jde J. A systematic review on clinical management of antipsychotic-induced sexual dysfunction in schizophrenia. Sao Paulo Med J 2006; 124: 291-297

144 Inder WJ, Castle D. Antipsychotic-induced hyperprolactinaemia. Aust N Z J Psychiatry 2011; 45: 830-837

145 Nunes LV, Moreira HC, Razzouk D et al. Strategies for the treatment of antipsychotic-induced sexual dysfunction and/or hyperprolactinemia among patients of the schizophrenia spectrum: a review. J Sex Marital Ther 2012; 38: 281-301

146 Schmidt HM, Hagen M, Kriston L et al. Management of sexual dysfunction due to antipsychotic drug therapy. Cochrane Database Syst Rev 2012, doi:10.1002/14651858.CD003546.pub3 